\title{
This time it's different? Effects of the Eurovision Debate on young citizens' and its consequence for EU democracy - evidence from a quasi-experiment in 24 countries
}

Jürgen Maier, Thorsten Faas, Berthold Rittberger, Jessica Fortin-Rittberger, Kalliope Agapiou Josifides, Susan Banducci, Paolo Bellucci, Magnus Blomgren, Inta Brikse, Karol Chwedczuk-Szulc, Marina Costa Lobo, Mikołaj Cześnik, Anastasia Deligiaouri, Tomaž Deželan, Wouter deNooy, Aldo Di Virgilio, Florin Fesnic, Danica Fink-Hafner, Marijana Grbeša, Carmen Greab, Andrija Henjak, David Nicolas Hopmann, David Johann, Gábor Jelenfi, Jurate Kavaliauskaite, Zoltan Kmetty, Sylvia Kritzinger, Pedro C. Magalhães, Vincent Meyer, Katia Mihailova, Mihail Mirchev, Ville Pitkänen, Aine Ramonaite, Theresa Reidy, Marek Rybar, Carmen Sammut, José Santana-Pereira, Guna Spurava, Lia-Paschalla Spyridou, Adriana Stefanel, Václav Štětka, Aleksander Surdej, Róbert Tardos, Dimitris Trimithiotis, Christiano Vezzoni, Aneta Világi \& Gergo Zavecz

To cite this article: Jürgen Maier, Thorsten Faas, Berthold Rittberger, Jessica Fortin-Rittberger, Kalliope Agapiou Josifides, Susan Banducci, Paolo Bellucci, Magnus Blomgren, Inta Brikse, Karol Chwedczuk-Szulc, Marina Costa Lobo, Mikołaj Cześnik, Anastasia Deligiaouri, Tomaž Deželan, Wouter deNooy, Aldo Di Virgilio, Florin Fesnic, Danica Fink-Hafner, Marijana Grbeša, Carmen Greab, Andrija Henjak, David Nicolas Hopmann, David Johann, Gábor Jelenfi, Jurate Kavaliauskaite, Zoltan Kmetty, Sylvia Kritzinger, Pedro C. Magalhães, Vincent Meyer, Katia Mihailova, Mihail Mirchev, Ville Pitkänen, Aine Ramonaite, Theresa Reidy, Marek Rybar, Carmen Sammut, José Santana-Pereira, Guna Spurava, Lia-Paschalla Spyridou, Adriana Stefanel, Václav Štětka, Aleksander Surdej, Róbert Tardos, Dimitris Trimithiotis, Christiano Vezzoni, Aneta Világi \& Gergo Zavecz (2017): This time it's different? Effects of the Eurovision Debate on young citizens' and its consequence for EU democracy - evidence from a quasi-experiment in 24 countries, Journal of European Public Policy, DOI: 10.1080/13501763.2016.1268643

To link to this article: http://dx.doi.org/10.1080/13501763.2016.1268643

View supplementary material $[ح$

Published online: 20 Jan 2017. 
Џll Article views: 148

Q View related articles $\square$

Q

$\bigodot_{\text {crossmatik }}$ View Crossmark data $\longleftarrow$

Full Terms \& Conditions of access and use can be found at http://www.tandfonline.com/action/journallnformation?journalCode=rjpp20 


\section{This time it's different? Effects of the Eurovision Debate on young citizens' and its consequence for EU democracy - evidence from a quasi-experiment in 24 countries}

Jürgen Maier ${ }^{\mathrm{a}}$, Thorsten Faas ${ }^{\mathrm{b}}$, Berthold Rittberger ${ }^{\mathrm{c}}$, Jessica FortinRittberger ${ }^{d}$, Kalliope Agapiou Josifidese, Susan Banducci ${ }^{\mathrm{f}}$, Paolo Bellucci ${ }^{\mathrm{g}}$, Magnus Blomgren ${ }^{\mathrm{h}}$, Inta Brikse ${ }^{\mathrm{i}}$, Karol Chwedczuk-Szulc', Marina Costa Lobok ${ }^{k}$ Mikołaj Cześnik', Anastasia Deligiaourim ${ }^{\mathrm{m}}$, Tomaž Deželan ${ }^{\mathrm{n}}$, Wouter deNooy ${ }^{\circ}$, Aldo Di Virgilio ${ }^{p}$, Florin Fesnic ${ }^{q}$, Danica Fink-Hafner ${ }^{n}$, Marijana Grbešar, Carmen Greab ${ }^{s}$, Andrija Henjak', David

Nicolas Hopmann ${ }^{\mathrm{t}}$, David Johann" ${ }^{\mathrm{u}}$, Gábor Jelenfi ${ }^{\mathrm{v}}$, Jurate Kavaliauskaite ${ }^{\mathrm{w}}$, Zoltan Kmetty ${ }^{v}$, Sylvia Kritzinger (10x), Pedro C. Magalhães ${ }^{k}$, Vincent Meyer ${ }^{y}$, Katia Mihailova ${ }^{\mathrm{z}}$, Mihail Mirchev ${ }^{\mathrm{aa}}$, Ville Pitkänen ${ }^{\mathrm{ab}}$, Aine Ramonaite ${ }^{\mathrm{ac}}$, Theresa Reidy ${ }^{\text {ad }}$, Marek Rybar ${ }^{\text {ae }}$, Carmen Sammut ${ }^{a f}$, José Santana-Pereira ${ }^{k}$, Guna Spurava $^{\text {ag }}$, Lia-Paschalla Spyridou ${ }^{\mathrm{e}}$, Adriana Stefanel ${ }^{\text {ah }}$, Václav Štětkaai, Aleksander Surdej ${ }^{\text {aj }}$, Róbert Tardos ${ }^{\text {ak }}$, Dimitris Trimithiotis ${ }^{\text {al }}$, Christiano Vezzoni ${ }^{\text {am }}$, Aneta Világi ${ }^{\text {an }}$ and Gergo Zavecz ${ }^{\text {ao }}$

aUniversity of Koblenz-Landau, Institute of Social Sciences, Landau, Germany; ${ }^{\text {b University of }}$ Mainz, Institute of Political Science, Mainz, Germany; ' LMU Munich, Institute of Political Science, Munich, Germany; dUniversity of Salzburg, Department of Political Science, Salzburg, Austria; 'University of Cyprus, Department of Social and Political Sciences, Nikosia, Cyprus; fUniversity of Exeter, Exeter Q-Step Centre, Exeter, UK; ${ }^{9}$ University of Siena, Department of

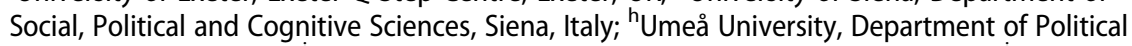
Science, Umeå, Sweden; 'University of Latvia, Faculty of Social Sciences, Riga, Latvia; 'University of Wrocław, Faculty of Social Sciences, Wrocław, Poland; ${ }^{k}$ University of Lisbon, Institute of Social Sciences, Lisbon, Portugal; 'University of Social Sciences and Humanities, Faculty of Arts and Social Sciences, Warsaw, Poland; 'mestern Macedonia University of Applied Sciences,

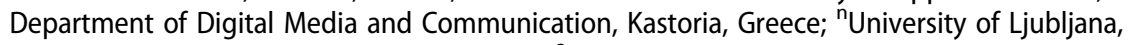
Faculty of Social Sciences, Ljubljana, Slovenia; ${ }^{\circ}$ University of Amsterdam, Amsterdam School of

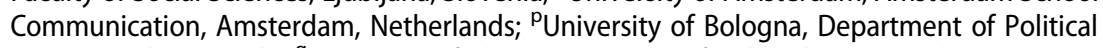
Science, Bologna, Italy; ' University of Cluj, Department of Political Science, Cluj, Romania; 'University of Zagreb, Faculty of Political Science, Zagreb, Croatia; 'University of Cluj, Department of Political Science, Cluj, Romania; 'University of Southern Denmark, Centre for Journalism, Department of Political Science, Odense, Denmark; "University of Vienna, German Centre for Higher Education Research and Science Studies, Vienna, Austria; 'Eötvös Lóránd University, MTA-ELTEPeripato Research Group, Faculty of Social Sciences, Budapest, Hungary;

CONTACT Jürgen Maier maierj@uni-landau.de

*Inta Brikse and Aldo Di Virgilio passed away before the paper was published. We are saddened by their loss and dedicate this paper to their memory.

(4) Supplemental data for this article can be accessed at http://dx.doi.org/10.1080/13501763.2016. 1268643

(C) 2017 Informa UK Limited, trading as Taylor \& Francis Group 
${ }^{w}$ Vilnius University, Institute of International Relations, Vilnius, Lithuania; ${ }^{x}$ University of Vienna, Department of Government, Vienna, Austria; ${ }^{y}$ University Nice Sophia Antipolis, Faculty of Humanities and Social Sciences, Nice, France; ${ }^{z}$ University of Sofia, Department of Economic

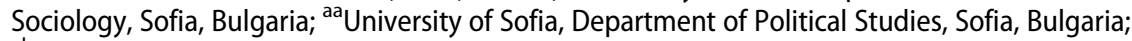
${ }^{\mathrm{ab}}$ University of Turku, Centre for Parliamentary Studies, Turku, Finland; ${ }^{\mathrm{ac}}$ Vilnius University,

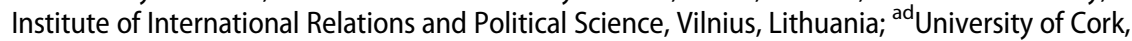
Department of Government, Cork, Ireland; ${ }^{\text {ae }}$ Masaryk University Brno, Department of Political Science, Brno, Czech Republic; ${ }^{\text {af }}$ University of Malta, Department of International Relations, Msida, Malta; ${ }^{a g}$ University of Latvia, Department of Communication Studies, Riga, Latvia; ${ }^{a h}$ University of Bucharest, Department of Journalism, Bucharest, Romania; ${ }^{\text {ai }}$ Charles University in Prague, Institute of Communication Studies and Journalism, Prague, Czech Republic; ${ }^{a j}$ Cracow University of Economics, Department of European Studies, Cracow, Poland; ${ }^{\text {ak }}$ ELTE University, Hungarian Academy of Sciences, Budapest, Hungary; ${ }^{\text {al } U n i v e r s i t y ~ o f ~ C y p r u s, ~}$ Department of Social and Political Sciences, Limassol, Cyprus; ${ }^{a m}$ University of Trento, Department of Sociology and Social Research, Trento, Italy; ${ }^{\text {an }}$ Comenius University in Bratislava, Department of Political Science, Bratislava, Slovakia; ${ }^{\text {ao } C e n t r a l ~ E u r o p e a n ~ U n i v e r s i t y, ~}$ Doctoral School of Political Science, Public Policy and International Relations, Budapest, Hungary

\begin{abstract}
For the very first time in EU history, the 2014 EP elections provided citizens with the opportunity to influence the nomination of the Commission President by casting a vote for the main Europarties' 'lead candidates'. By subjecting the position of the Commission President to an open political contest, many experts have formulated the expectation that heightened political competition would strengthen the weak electoral connection between EU citizens and EU legislators, which some consider a root cause for the EU's lack of public support. In particular, this contest was on display in the so-called 'Eurovision Debate', a televised debate between the main contenders for the Commission President broadcasted live across Europe. Drawing on a quasi-experimental study conducted in 24 EU countries, we find that debate exposure led to increased cognitive and political involvement and EU support among young citizens. Unfortunately, the debate has only reached a very small audience.
\end{abstract}

KEYWORDS EP election campaign; EU attitudes; political knowledge; televised debate

\title{
Introduction
}

Concerns about the European Union's (EU) democratic qualities are as old as the European integration project itself, as are suggestions and attempts to remedy the EU's democratic deficit. The creation and gradual expansion of the European Parliament's (EP) prerogatives and, in particular, the introduction of direct elections to the EP in 1979, are among the major institutional innovations to address this deficit (see, e.g., Rittberger 2012; Tulli 2016). However, expectations that the empowerment of the EP over time and the introduction of direct elections would strengthen the electoral connection between citizens and elected EU legislators have been largely disappointed (see Hix and Hoyland 2013). In sharp contrast to national elections and parliaments, EP elections are much less attractive to voters, as the considerably 
lower (and declining) turnout rates indicate. Consequently, EP elections have been referred to as 'second-order national elections' (Reif and Schmitt 1980). Parties, media and ultimately also voters treat them as national contests, with EU-related issues taking a backseat.

Follesdal and Hix (2006) have advanced a powerful argument that the key to mend the weak electoral connection is to foster political competition at the EU-level. Absent a true electoral contest at the EU-level, whose outcome would affect the course of the EU's policy agenda and absent a choice to determine the EU's top political personnel, the electoral connection is likely to stay weak (Follesdal and Hix 2006: 552). While battles over the direction of the EU's policy agenda have become a regular feature of political decision-making inside the EP as well as between the EP and the Council (Hix and Hoyland 2013), these developments have, thus far, not affected electoral competition in the run-up to EP elections. At the same time, aspirations are high that a contest over the EU's (top) personnel decisions might be more effective in infusing competition in the electoral campaign preceding EP elections: One of the most important posts in the EU's political system is the President of the European Commission, who defines the Commission's work programme and thus sets its policy-making priorities. For many observers, the 'role of the Commission is not fundamentally different from other political executives.' (Follesdal and Hix 2006: 554; Hix 2008: 155). Hence, subjecting the office of the Commission President to an open political contest rather than letting heads of state and government pick their preferred candidate in 'smoked filled rooms' has become a battle call for academics, pundits and politicians sharing concerns about the EU's democratic deficit and lack of political competition. A contest for one of the EU's top political offices should contribute to mend the electoral connection: Citizens are likely to be better informed about EU policy objectives when there are competitive elections and higher stakes, they should also be more motivated to participate in EP elections, and possibly confer a higher degree of legitimacy and the EU as a polity (see, e.g., Follesdal and Hix 2006; Hix 2008).

With the entry into force of the Lisbon Treaty in 2009, political activists and elites were now presented with a new institutional mechanism, which was premised on the idea to connect voters with the exercise of political power at the EU-level. ${ }^{1}$ Prior to the Lisbon Treaty, the European Council nominated a candidate for Commission President, and once the heads of state and government had made up their minds, the chosen candidate was submitted to the EP for approval. Article 17(7) of the Treaty on European Union, which was amended through the Lisbon Treaty, now stipulates:

Taking into account the elections to the European Parliament and after having held the appropriate consultations, the European Council, acting by a qualified majority, shall propose to the European Parliament a candidate for President of 
the Commission. This candidate shall be elected by the European Parliament by a majority of its component members. (Publications Office of the European Union 2010: 26)

In the run-up to the 2014 EP elections, political pressure emanated from the Commission and the EP, as well as from several national capitals to fundamentally alter the nomination process for the successor of José Manuel Barroso, then Commission President at the time. Both, Barroso, the main party groups in the EP, and the majority of transnational European party groups (Europarties) called for a process whereby each Europarty would nominate a 'lead candidate' for the Commission's top office. These lead candidates would, in turn, play a central role in the political campaign for the 2014 EP elections. While the implementation of the lead candidate-concept was hotly contested (see, e.g., Hobolt 2014), it also marked a watershed, since each Europarty did in fact nominate a transnational candidate for the Commission's top post.

The 2014 EP election campaign thus provides for an ideal quasi-experimental setting to explore whether the expectation that increased political competition improves the electoral connection and hence the quality of democracy is borne out in reality. In this article, our focus is on one particular innovation of the 2014 EP election campaign, which is directly connected to the contest of different lead candidates for the position of Commission President: The campaign included a series of televised debates among these candidates, the most prominent of which took place on 15 May 2014. The so-called 'Eurovision debate', a multilingual 90-minute discussion among the Europarty nominees for Commission President, addressed some of the most pressing problems facing the EU and was broadcasted on numerous TV stations, radio channels and internet streams throughout and even beyond the EU. The Eurovision debate was the culmination of a series of televised debates (totalling seven) during the 2014 EP election campaign. What rendered the Eurovision debate special compared to the other debates was that it starred all five top candidates for the post, whereas in the other debates only two to four candidates were invited (sometimes not even including the top candidates). Moreover, the Eurovision debate was broadcasted in the vast majority of the EU member states, while the other debates were aired in only a subset of member states (for an overview see Maier and Faas 2014).

Hence, for the very first time in the history of the EU an overwhelming majority of EU citizens had the unprecedented opportunity to compare the positions and personalities of the candidates running for Commission President in a campaign format familiar from the context of national elections. In this article we inquire whether the debate generated the desired effect, i.e., did it contribute to improving the EU's democratic quality because EU citizens now have an actual opportunity to influence who will be the next 
Commission President $?^{2}$ The literature on televised debates at the national level has demonstrated that these campaign formats affect voters, i.e., their cognitions, motivations, attitudes, and even voting choices. Whether this has been the case in the 2014 European election and whether the TV debate format incites electoral competition are open questions, which this article sets out to address. To do so, we present the results of a quasi-experimental study with young voters conducted in $24 \mathrm{EU}$ member states. Since we have carried out a quasi-experiment with self-selected student samples, our data are neither representative for any of the countries under investigation nor for young voters. Hence, like other lab-experiments our data lack external validity. Nevertheless, these data are very valuable as it has a high degree of internal validity. In addition, there is evidence that voluntary student samples are appropriate for experimental effect studies (see Druckman and Kam 2011).

We proceed as follows: In the next section (2.), we will bring together some of the key arguments from the EU's democratic deficit-debate, hinted at above, and the literature on televised debates to develop expectations about the possible effects of the Eurovision debate on voters: This will allow us to analyse, in the next step, whether political competition improves voter knowledge about candidates, whether it motivates them to cast a vote, and whether competition affects EU-related attitudes. In section 3, we describe the research design and data, followed by an empirical analysis of the impact of the Eurovision debate (4.). Our results show that the debate had a recognizable impact on our respondents, indicating higher cognitive and political involvement, as well as attitudinal changes. In the final section (5.) we will critically discuss these findings and suggest avenues for further research.

\section{Electoral competition and EU support: insights from research on TV debates}

Following Robert Dahl (1971), a democratic polity ought to be responsive to the preferences of its citizens, and for government to be responsive it has to provide guarantees for effective public participation as well as for public policies and electoral offices to be open to public contestation. Moreover, for decisions to be meaningful and informed there has to be access to alternative sources of information. Follesdal and Hix (2006) echo the Dahlian perspective on democracy when they diagnose that a lack of public contestation is at the core of the EU's democratic legitimacy deficit. Introducing contestation by means of a debate on EU issues combined with an electoral contest about the EU's top executive post should, so they argue, lessen the legitimacy deficit and mend the electoral connection between citizens and EU legislators (Hix 2008: 86). What about the mechanisms linking electoral competition and a growing sense of democratic legitimacy? Political contestation strengthens the 
subjective content of democracy by providing a battle for control of political power and the policy agenda at the European level, between rival groups of leaders with rival policy platforms, where the winner and losers of this battle are clearly identifiable (Hix 2008: 85).

More competition 'would also enable citizens to understand European policy issues, to form opinions about the options available, and in time accept why certain reforms are necessary rather than reject any policy change directed from Brussels as illegitimate' (Hix 2008: 108). Heightened political contestation and debate are thus hypothesized to affect citizens' attitudes toward the EU and, in turn, positively impact the EU's perceived democratic quality. Could exposure to a televised debate among the top candidates for the Commission Presidency affect voters' knowledge about the EU, increase their motivation and ability to form opinions about EU issues, as suggested by the proponents of instilling more political contestation into the EU arena?

First, a televised debate in the run-up to the EP elections could have an impact on citizens' political cognitions: 'A debate would make the candidates more widely recognizable, and enable [...] the public to understand the personal and policy differences between the candidates' (Hix 2008: 161). More precisely, Hix (2008: 162) suggests 'the public would be able to identify who the Commission president is and what he or she aims to achieve'. Turning to the debate literature, the majority of debate researchers agree that viewers do learn from debates - subjectively as well as objectively. After watching a debate, recipients usually know more about the issues debated and candidates debating them. Learning effects are particularly pronounced for less known candidates (see, e.g., Holbrook 1999; Zhu et al. 1994) and candidates running for one's 'own' party (see, e.g., Abramowitz 1978; Jacoby et al. 1986). In addition, recipients do not only learn factual information. They often also consider themselves better informed about politics afterwards than prior to the debate (see, e.g., Kaid et al. 2000). This effect has already been demonstrated for German viewers of the Eurovision debate (Dinter and Weissenbach 2015). Based on these findings, we could expect that a debate among candidates for the post of Commission President should lead to a greater awareness of the candidates and their respective stances on EU policies. We therefore expect that watching the debate increases the ability of viewers' to make judgements about the candidates' personal and political profiles ( $\mathrm{H} 1)$. In addition, we expect that debate exposure increases viewers' sense about being informed about the EU and EU politics $(\mathrm{H} 2)$.

Second, more competitive and consequential elections could also have an effect on the motivations underlying political involvement and political participation. Hix (2013: 11) states this expectation quite clearly: 'If a party-based contest for the President of the Commission emerges in 2014 [ ... ] some citizens in Europe would feel they have influenced the choice of the most powerful office in the EU for the first time.' Moreover, Follesdal and Hix (2006: 550) assume that 'competition fosters political debate' and thus assume that 
exposure to a leadership contest should increase campaign interest and campaign communication. It should also instil a sense of internal efficacy, i.e., the feeling that people have some means of influence on EU politics. The debate literature provides ample evidence that debates can stimulate the motivations underlying electoral participation. In particular, it has been demonstrated that watching televised debates usually increases campaign interest (see, e.g., Pfau 1987; Weaver and Drew 2001). Moreover, debate viewership correlates with higher turnout (see, e.g., Best and Hubbard 1999). In particular, it positively affects participation of voters with a low level of campaign interest (Maier and Faas 2011). There is less conclusive evidence when it comes to the effects on viewers' feeling of internal efficacy. Based on the findings in the existing literature, we expect that exposure to a televised debate will increase campaign interest (H3). Given the new features of the 2014 EP election campaign with 'lead candidates' competing for the office of Commission President, we also expect that watching the debate will strengthen viewers' feeling of internal efficacy $(\mathrm{H} 4)$ even though there is little evidence in the literature pertaining to this so far (see, e.g., Hobolt 2014). Viewers might very well understand though that - for the very first time since the first direct elections to the EP in 1979 - they have an actual say in deciding on the EU's top personnel and the EU's political agenda. After all, Monica Maggioni, the moderator of the Eurovision debate, as well as Alexis Tsipras and Martin Schulz emphasized in the course of the televised debate that one of the European parties' top candidates would serve as the next Commission President, which also reflected the overall media tone in the run-up to the election - even though some national governments were hesitant to fully accept the new procedure prior to the elections. Overall, we think that there is good reason to believe that the audience of the debate accepted these claims, which in turn leads us to expect a positive effect of watching the debate on viewers' internal efficacy.

Third, heightened political competition can have consequences for political attitudes about the EU. Follesdal and Hix (2006: 550) posit 'political competition is an essential vehicle for opinion formation. Competition fosters political debate, which in turn promotes the formation of public opinion on different policy options'. Following this line of reasoning, political competition could potentially counteract the second-order character of EP elections, which still 'have very little to do with "Europe"' (Hix 2008: 79). Thus, boosting political competition should increase the relevance of candidates running for office at the EU-level and of EU issues. ${ }^{3}$ More precisely, Hix (2008) claims that, instead of focussing on the national policy agenda more electoral competition will highlight the relevance of EU issues and contribute to the EU's perceived legitimacy. Turning to the debate literature, the actual influence of debates on political attitudes (and voting behaviour, which is not the focus of this contribution) is heavily disputed. While two meta-analyses (Benoit et al. 2003; McKinney and Warner 2013) indicate that viewing televised debates affects 
issue preferences, attitudes towards the candidates as well as voting behaviour, most studies on debates in the U.S. suggest that debates can only reinforce already existing attitudes and voting intentions rather than transform them (for a summary see McKinney and Carlin 2004). These findings tie in with the results from classical campaign research that a reinforcement of existing attitudes and voting intentions is the most important campaign effect. Mechanisms of selective exposure and selective information processing usually prevent individuals from receiving 'wrong', i.e., contradictory information, and thus from changing their attitudes (Lazarsfeld et al. 1944). On the other hand, debate exposure strengthens the perceived importance of the issues debated (see, e.g., Benoit et al. 2003). The picture for debates in European states is less clear-cut. For some European countries the impact of debates seems to be rather limited (e.g., Maricchiolo et al. 2010), whereas studies for other countries suggest that debates are more persuasive. For instance, it has been demonstrated that almost one fifth of the Croatian voters changed their voting intention after the 2005 debates (Skoko 2005). Furthermore, significant parts of the German electorate changed their opinions about the respective candidates running for chancellor and even revised their voting intentions after watching a debate (see, e.g., Maier and Faas 2011). The strongest impact was observed for citizens not identifying with a particular political party, but there were also significant conversion effects for people with an existing party attachment (see, e.g., Maier and Faas 2011). In addition, existing research also indicates that the Eurovision debate affected candidate evaluations. Most of the candidates for Commission President were perceived more positively by German voters after watching the debate (Dinter and Weissenbach 2015). In addition, exposure to the debate significantly increased favourable opinions about EU integration and reduced fears about the EU (Maier et al. 2016).

Finally, debates can also have an impact on more general attitudes about the political system. The few studies available indicate that watching debates causes more favourable evaluations of the political system (Wald and Lupfer 1978). This is particularly true for young German voters following the Eurovision Debate (Maier 2015). Based on these findings, we contend that exposure to the Eurovision debate should increase the perception that important problems should be solved by the EU (rather than at the national level) (H5). Furthermore, based on studies indicating that positive media coverage of the EU should lead to more positive EU attitudes (for a summary see, e.g., Hobolt and Tilley 2014: 87) as well as on research suggesting that one major focus of the Eurovision debate was to highlight the virtues of the EU (de Vreese and van der Brug 2016), we expect debate viewership to result in more positive attitudes about the EU as a polity (H6). These expectations are consistent with the findings that televised debates can have agenda-setting effects and increase positive attitudes about the political system as a whole. 


\section{Research design}

To assess the impact of the Eurovision Debate ${ }^{4}$ among the five top candidates nominated by the respective Europarties - Jean-Claude Juncker (European People's Party), Martin Schulz (Progressive Alliance of Socialists and Democrats), Guy Verhofstadt (Alliance for Democrats and Liberals for Europe), Ska Keller (Greens/European Free Alliance), Alexis Tsipras (European United Left) - we set up a quasi-experimental pretest-posttest study in 24 European countries (for details see online appendix 1). In total, 828 eligible voters (mostly students) watched the debate as it was broadcasted live on a large screen in their respective universities. ${ }^{5}$ Reception modes differed across countries, depending on whether or not a national broadcasting station aired the debate. 78.0 per cent of the participants were able to watch the debate simultaneously, translated in their national language; 13.8 per cent watched the original version of the debate as provided by the European Broadcasting Union (EBU; candidates were either speaking in English or with simultaneous translation into English), although this was in most cases not the native language of our participants. ${ }^{6}$ Immediately prior and immediately after the debate the participants were asked to fill in questionnaires. ${ }^{7}$ The questionnaires included questions on campaign interest, attitudes towards European integration, knowledge about the EU, knowledge about and attitudes towards the candidates, expectations about (posttest: perceptions of) the debate and the candidates' debate performance, perceptions of the EP election campaign, voting intentions, demographics (pretest only), and - in cases the debate was not provided in the respondents' mother tongue how well they understood the debate ${ }^{8}$ (posttest only). ${ }^{9}$

In general, the basic design of this study is similar to a design, which has been successfully applied in the past to explore the impact of televised debates in Germany for a series of debates there (see, e.g., German Longitudinal Election Study 2014; Maier and Faas 2003; Maurer et al. 2007). Such a strict pretest-posttest design, in which participants fill out questionnaires immediately prior to the debate and also directly afterwards, allows us to trace possible effects of the debate - in line with our hypotheses presented above - on the participants of the study in a rigorous manner. We do want to stress, though, that the design of our study does not include a control group. Strictly speaking, without such a control group, we are not able to separate effects of the pretest questionnaire from effects of the treatment (i.e., the debate). As there is evidence that our sample does not suffer from questionnaire effects we consider any statistically significant deviation from zero as an impact of the debate. ${ }^{10}$ Other data confirm this assessment. ${ }^{11}$

In order to analyse the data we decided to weight the countries according to their population size. The basic idea behind this weighting procedure is to get an impression of how young and well-educated citizens across Europe 
respond to the campaign. By weighting the data we want to avoid that our results are affected by the scholars' resources, opportunities, and experiences with experimental research, which might have affected the sample sizes obtained in the individual countries. ${ }^{12}$ The weighted data set includes 51.8 per cent female respondents (minimum: 7.7 per cent in Slovenia; maximum 81.0 per cent in Romania; $F=1.98, \mathrm{~d} f=23, p<.01$ ). The average age is 22.9 years (minimum: 20.0 years in Lithuania; maximum: 29.7 years in Ireland; $F=6.33, \mathrm{~d} f=23, p<.001) .93 .6$ per cent of the participants are students (minimum: 83.3 per cent in France; the sample consists exclusively of students in Bulgaria, Croatia, Czech Republic, Denmark, Finland, Greece, Hungary, Portugal, and Sweden; $F=2.41, \mathrm{~d} f=23, p<.001)$. Most of the students are enrolled in a political science programme (38.5 per cent), a social science programme (23.2 per cent), or a programme in communication studies (18.0 per cent). 20.3 per cent of the students were enrolled in another programme $\left(X^{2}=\right.$ $653.47, \mathrm{~d} f=69, p<.001)$. From those participants who followed the debate in English, without English being their native language, 1.4 per cent indicated that they understood less than 50 per cent of what the candidates said. On average, participants exposed to the English version of the debate indicated that they understood 84.5 per cent of all candidate messages (minimum: 67.0 in Latvia; maximum: 90.6 per cent in Finland; $F=3.51$, $f f=8, p<.01$ ).

Our sample is, of course, neither representative for any of the countries under investigation nor for young voters. As experiments in general, our data lack external validity. Nevertheless, our design is useful for assessing debate effects. First, different to survey data experiments have a high internal validity. We know that the participants of our study were exposed to the debate. Hence, shifts in attitudes have to be considered as debate-induced changes. Second, we have no indication that the processing of the debate and its effects are different for voters not included in our sample. Although various scholars argue that voluntary student samples are too 'narrow' to draw more general conclusions, other researchers have found that those samples are appropriate to study social behaviour (Druckman and Kam 2011; Exadaktylos et al. 2013). Since we are interested in the effect of the debate (and not in distributions of EU-attitudes), we contend that our findings are valid for young and well-educated European voters in general.

\section{Results}

\section{Debate effects on political cognitions}

With reference to $\mathrm{H} 1$ we expect that exposure to the Eurovision debate should increase the voters' ability to evaluate the candidates' personal and political profile. This expectation is clearly corroborated (see Table 1). Prior to the debate, the average viewer was only able to describe his/her feelings toward a 
Table 1. Impact of the Eurovision debate on political cognitions.

\begin{tabular}{|c|c|c|c|c|c|c|}
\hline & $\begin{array}{l}\text { Before } \\
\text { the } \\
\text { debate }\end{array}$ & $\begin{array}{c}\text { After } \\
\text { the } \\
\text { debate }\end{array}$ & $\begin{array}{c}\text { Difference; } \\
\text { significance of } \\
\text { difference }\end{array}$ & $\begin{array}{c}\text { Strongest } \\
\text { negative } \\
\text { effect }\end{array}$ & $\begin{array}{c}\text { Strongest } \\
\text { positive } \\
\text { effect }\end{array}$ & $\begin{array}{c}\text { Significance of } \\
\text { country } \\
\text { differences }\end{array}$ \\
\hline $\begin{array}{l}\text { Number of } \\
\text { candidates } \\
\text { rated by } \\
\text { sympathy }\end{array}$ & 2.38 & 4.99 & $+2.61, p<.001$ & +.95 & +4.00 & $p<.001$ \\
\hline $\begin{array}{l}\text { Number of } \\
\text { candidates } \\
\text { rated by } \\
\text { ideological } \\
\text { position }\end{array}$ & 2.16 & 4.84 & $+2.68, p<.001$ & +1.00 & +4.05 & $p<.001$ \\
\hline $\begin{array}{l}\text { Number of } \\
\text { candidates } \\
\text { rated by } \\
\text { position on EU } \\
\text { integration }\end{array}$ & 1.96 & 4.84 & $+2.88, p<.001$ & +1.37 & +4.30 & $p<.001$ \\
\hline $\begin{array}{l}\text { Information } \\
\text { about EU } \\
\text { politics }\end{array}$ & -.30 & -.04 & $+.26, p<.001$ & -.17 & +.72 & $p<.001$ \\
\hline
\end{tabular}

Notes: Sympathy of the candidates: 'How would you describe your feelings toward the candidates of tonight's debate?'; respondents could indicate that they do not know. Based on this information, a six-point scale from 0 ('cannot describe a feeling for any of the candidates') to 5 ('can describe a feeling for each of the candidates') was created; Portugal has been excluded from the analysis of this question as the candidates' sympathy ratings were not asked in the Portuguese posttest survey. Candidate ideological position: 'In political matters people talk of 'the left' and 'the right". What is the position of [candidate]?'; six-point scale from 0 ('do not perceive a position for any of the candidates') to 5 ('perceive a position for each of the candidates'). Candidate position on EU integration: 'Some say European integration (i.e., the economic and political cooperation between the member states) should be pushed further. Others say it has already gone too far. What do you think is the position of [candidate] on this issue?'; six-point scale from 0 ('do not perceive a position for any of the candidates') to 5 ('perceive a position for each of the candidates'). Information about EU politics: 'I am very well informed about EU politics'; five-point scale from -2 ('strongly disagree') to +2 ('strongly agree').

minority of the candidates $(M=2.38)$. After the debate almost every respondent had an opinion about all of the five candidates $(M=4.99)$. This increase is statistically significant $(p<.001)$. The same pattern holds for the candidates' political positions. Before the debate, respondents could state an ideological position for, on average, 2.16 candidates and on EU integration for, on average, 1.96 candidates. After the debate, ideological respectively EU positions are reported for, on average, 4.84 candidates. These increases $(+2.68$ respectively +2.88 ) are statistically significant $(p<.001)$. Although there is a positive impact of debate exposure for both the personal and the political profile of the candidates in all countries, the effect varies considerably across countries. For all three variables the country-specific impact of the debate is significant $(p<.001)$.

We also expect that exposure to the Eurovision debate should increase the perceived level of information about EU politics $(\mathrm{H} 2)$, which is confirmed by our analysis. Overall, the level of subjective information increases from -.30 before the debate to -.04 after the debate. This shift of .26 scale points is statistically significant $(p<.001)$. The maximum effect is +.72 , while the strongest 
Table 2. Impact of the Eurovision debate on perceived candidates' ideological positions and positions on EU integration.

\begin{tabular}{|c|c|c|c|c|c|c|}
\hline & $\begin{array}{l}\text { Before } \\
\text { the } \\
\text { debate }\end{array}$ & $\begin{array}{c}\text { After } \\
\text { the } \\
\text { debate }\end{array}$ & $\begin{array}{l}\text { Difference; } \\
\text { significance of } \\
\text { difference }\end{array}$ & $\begin{array}{c}\text { Strongest } \\
\text { negative } \\
\text { effect }\end{array}$ & $\begin{array}{l}\text { Strongest } \\
\text { positive } \\
\text { effect }\end{array}$ & $\begin{array}{l}\text { Significance } \\
\text { of country } \\
\text { differences }\end{array}$ \\
\hline \multicolumn{7}{|l|}{ Ideological position } \\
\hline Juncker & 6.56 & 6.63 & $+.07, p>.05$ & -1.94 & +2.33 & $p>.05$ \\
\hline chulz & 1 & 3.83 & $-.18, p<.05$ & 0 & & $>.05$ \\
\hline Verhofstadt & & 6.00 & $-.10, p>.05$ & & & \\
\hline Tsipras & 2.83 & 1.87 & $-.97, p<.001$ & -5.40 & 30 & $p<.05$ \\
\hline enter & 4 & 4 & -1.30 & 3 & 8 & 5 \\
\hline Candidate polarization & 4.46 & 6.24 & $+1.78, p<.001$ & -.06 & & $p<.001$ \\
\hline \multicolumn{7}{|l|}{ Position on EU integration } \\
\hline Juncker & 5.77 & 6.60 & $+.83, p<.001$ & -2.75 & 00 & $p<.001$ \\
\hline Sche & 6.34 & 6.78 & $+.44, p<.001$ & -1.79 & & $p>.05$ \\
\hline fstadt & 5.44 & 6.56 & $+1.12, p<.001$ & -1.75 & 25 & $p>.05$ \\
\hline ipras & 5.65 & 5.74 & .05 & 0 & & $p>.05$ \\
\hline Keller & 6.24 & 6.80 & $+.56, p<.01$ & -2.50 & +6.00 & $p>.05$ \\
\hline Candidate polarization & 3.54 & 4.09 & $+.55, p<.001$ & -4.75 & +1.73 & $p<.01$ \\
\hline \multicolumn{7}{|c|}{$\begin{array}{l}\text { Notes: Analyses are based on subjects evaluating the respective candidates before and after the debate; } \\
N_{\text {Ideology }}=(285 ; 511), N_{\mathrm{EU}} \text { Integration }=(269 ; 474) \text {. Candidate ideological position: 'In political matters } \\
\text { people talk of "the left" and "the right". What is the position of [candidate]?'; eleven-point scale from } \\
0 \text { ('left') to } 10 \text { ('right'). Candidate position on EU integration: 'Some say European integration (i.e., the } \\
\text { economic and political cooperation between the member states) should be pushed further. Others } \\
\text { say it has already gone too far. What do you think is the position of [candidate] on this issue?'; } \\
\text { eleven-point scale from } 0 \text { ('European integration has already gone too far') to } 10 \text { ('European integration } \\
\text { should be pushed further'). Candidate polarization: absolute difference between the candidate perceived } \\
\text { as ideological most left and the candidate perceived as ideological most right respectively between the } \\
\text { candidate perceived as most in favour of further EU integration and the candidate perceived as most } \\
\text { critical of further EU integration. }\end{array}$} \\
\hline
\end{tabular}

negative effect is -.17 . Again, our results indicate that reactions to the debate differ significantly across countries $(p<.001)$.

The Eurovision debate did not only help recipients to develop first-time attitudes towards the candidates. We also see that respondents who already had an opinion about the contenders shifted their perceptions of the candidates' ideological positions and of their stance on EU integration (see Table 2). With respect to ideology, all candidates are perceived to stand further to the left after than before the debate (with the exception of Juncker). For Schulz $(p<.05)$, Tsipras $(p<.001)$ and Keller $(p<.001)$, these change are statistically significant. In addition, the perceived ideological polarization among the candidates has increased in the wake of the debate. The average ideological distance between the candidate perceived as most to the left and the candidate perceived as most to the right increases from 4.46 to 6.24 scale points $(p<.001)$.

Furthermore, the debates helped citizens to develop and sharpen their views about the candidates' positions on EU integration. All candidates are perceived as more pro-EU after the debate. Except for Tsipras $(p>.05)$, all changes are statistically significant. In addition, the debate provided viewers with information helping them to distinguish the candidates. As a consequence, the perceived polarization between the contenders has significantly increased from, on average, 3.54 to 4.09 scale points $(p<.001)$. 


\section{Debate effects on motivations}

We also hypothesized that watching the debate will positively affect the motivations underlying electoral participation. In particular, exposure to the debate should lead to an increase in campaign interest $(\mathrm{H} 3)$ as well as to a stronger sense of internal efficacy $(\mathrm{H} 4)$. We can confirm both hypotheses. With respect to internal efficacy, we observe a significant increase from .19 before the debate to .26 after the debate (Table 3). The shift of +.07 scale points is statistically significant. Still, in four out of 24 countries, we observe that internal efficacy has decreased. The maximum effect is -.33 . In contrast, exposure to the debate has stimulated an increase in internal efficacy in the overwhelming majority of countries. The maximum effect is +.41 .

In addition, we see a significant increase in campaign interest. Starting from 1.83 scale points before the debate, campaign interest rose by .26 scale points to 2.09 scale points after the debate. In each of the countries under investigation, campaign interest has increased. The smallest effect is +.04 , the largest +.70 . Although in most countries the impact of the debate on motivation turned out to be positive, the size of the effects significantly differ across countries for internal efficacy $(p<.001)$ as well as campaign interest $(p<.01)$.

\section{Debate effects on political attitudes}

With respect to political attitudes we argued that the importance attached to EU issues is likely to rise if citizens were exposed to the Eurovision debate (H5). In addition, we have claimed that attitudes towards the EU should become more favourable as a consequence of debate exposure (H6). $\mathrm{H} 5$ can be confirmed. The share of respondents who indicate that the most pressing political problem at the domestic level should now be solved at the EU level increased from 44.5 per cent before the debate to 52.9 per cent after the debate (Table 4). The increase of 8.4 percentage points is statistically significant. However, in three out of the 24 countries under investigation, we observed the opposite

Table 3. Impact of the Eurovision debate on motivations.

\begin{tabular}{ccccccc}
\hline & $\begin{array}{c}\text { Before } \\
\text { the } \\
\text { debate }\end{array}$ & $\begin{array}{c}\text { After } \\
\text { the } \\
\text { debate }\end{array}$ & $\begin{array}{c}\text { Difference; } \\
\text { significance of } \\
\text { difference }\end{array}$ & $\begin{array}{c}\text { Strongest } \\
\text { negative } \\
\text { effect }\end{array}$ & $\begin{array}{c}\text { Strongest } \\
\text { positive } \\
\text { effect }\end{array}$ & $\begin{array}{c}\text { Significance of } \\
\text { country } \\
\text { differences }\end{array}$ \\
\hline $\begin{array}{c}\text { Internal } \\
\text { efficacy }\end{array}$ & .19 & .26 & $+.07, p<.01$ & -.33 & +.41 & $p<.001$ \\
$\begin{array}{c}\text { Campaign } \\
\text { interest }\end{array}$ & 1.83 & 2.09 & $+.26, p<.001$ & +.04 & +.70 & $p<.01$ \\
\hline
\end{tabular}

Notes: Internal efficacy: (a) 'Sometimes politics and government seem so complicated that a person like me can't really understand what's going on.', (b) 'I have a pretty good understanding of what is going on in politics.'; five-point scale from -2 ('strongly disagree') to +2 ('strongly agree'); after item a) has been reversed both variables were put together into an index running from -2 ('low internal efficacy") to +2 ('high internal efficacy').Campaign interest: 'And to what extent would you say are you interested in the current European election campaign?'; four-point scale from 0 ('not at all') to 3 ('very'). 
Table 4. Impact of the Eurovision debate on political attitudes.

\begin{tabular}{lcccccc}
\hline & $\begin{array}{c}\text { Before } \\
\text { the } \\
\text { debate }\end{array}$ & $\begin{array}{c}\text { After } \\
\text { the } \\
\text { debate }\end{array}$ & $\begin{array}{c}\text { Difference; } \\
\text { significance of } \\
\text { difference }\end{array}$ & $\begin{array}{c}\text { Strongest } \\
\text { negative } \\
\text { effect }\end{array}$ & $\begin{array}{c}\text { Strongest } \\
\text { positive } \\
\text { effect }\end{array}$ & $\begin{array}{c}\text { Significance of } \\
\text { country } \\
\text { differences }\end{array}$ \\
\hline $\begin{array}{l}\text { Most important } \\
\text { national } \\
\text { problem } \\
\text { should be }\end{array}$ & 44.5 & 52.9 & $+8.4, p<.001$ & -16.0 & +37.5 & $p<.01$ \\
$\begin{array}{c}\text { solved by EU } \\
\text { psition on EU } \\
\text { integration } \\
\text { Evaluation of EU } \\
\text { membership }\end{array}$ & 1.06 & 1.45 & $+.39, p<.001$ & -.21 & +1.58 & $p<.05$ \\
\hline
\end{tabular}

Notes: Most important problem: 'What do you think would be the most appropriate level to deal with those three problems that you have just mentioned?'; 1 = 'European level', 2 ='national level', $3=$ 'regional/ local level'; code 1 was multiplied by 100, codes 2 and 3 are recoded into code 0 . EU integration: 'Some say European integration (i.e., the economic and political cooperation between the member states) should be pushed further. Others say it has already gone too far. What is your opinion on this issue?' Eleven-point scale from -5 ('European integration has already gone too far') to + 5 ('European integration should be pushed further'). EU membership: 'Generally speaking, do you think that your country's membership of the European Union is a good thing, a bad thing, or neither good nor bad?'; three-point scale from -1 ('bad thing') to +1 ('good thing').

trend. The strongest negative impact is -16.0 percentage points. Nevertheless, the perceived relevance of the EU increased in most countries. The largest effect is +37.5 percentage points.

In addition, the data indicate that debate exposure causes more pro-EU attitudes. In particular, the already rather favourable view towards European integration $(M=1.06)$ has become more favourable as a result of debate exposure $(M=1.45)$. This increase is statistically significant (+.39 scale points, $p<.001)$. At the country level, the strongest negative impact is -.21 , the largest positive effect is +1.58 . In contrast to these findings, general support of one's country EU membership remained by-and-large unchanged $(M=.65$ before vs. $M=.63$ after the debate, difference: -.02 scale points, $p>.05)$. Hence, H6 can only partially supported. In seven out of 24 countries we observe a decline of EU support. The strongest negative impact of the debate is -.40 scale points. Nevertheless, in the majority of countries, respondents developed more favourable EU attitudes as a consequence of debate reception. The strongest effect is +.33 scale points. For all variables under investigation we observe very different responses across the different EU member states, which pass the levels for statistical significance (at least $p<.05$ ).

\section{Discussion and conclusion}

Our data, which reflects the attitudes and perceptions of young and well-educated voters across $24 \mathrm{EU}$ member states, suggests that exposure to the debate caused higher cognitive and political involvement. In particular, exposure to the debate enabled our respondents to make more informed 
judgements of the candidates' personality and political profile $(\mathrm{H} 1)$. Even those viewers who had an opinion about the candidates' ideological position and their stance on EU integration prior to the debate displayed a tendency to change their perceptions afterwards. Most noteworthy is that the perceived polarization among the candidates has increased due to debate reception. This is true for both dimensions. Despite some doubts expressed in the literature (see, e.g., de Vreese and van der Brug 2016), the debate clearly helped voters to distinguish the candidates running for Commission President. Moreover, watching the debate also increased the overall level of information about EU politics $(\mathrm{H} 2)$, led to a heightened sense of internal efficacy, i.e., the belief that one can influence politics $(\mathrm{H} 3)$, and a stronger interest in the campaign ( $\mathrm{H} 4)$. In addition, having watched the debate also led respondents to display stronger agreement with the claim that the most important political problems of one's own country should be solved at the EU-level (H5). Furthermore, viewers also tended to hold more positive evaluations about the EU. Since we could not observe this pattern for all EU-related attitudes, $\mathrm{H} 6 \mathrm{can}$ only partially supported. ${ }^{13}$

Overall, our results indicate that exposure to the Eurovision Debate has been conducive to infuse the EP election campaign with a dose of political competition, thereby tackling one of the professed causes of the EU's democratic legitimacy deficit. We have demonstrated that by watching the debate, our respondents have not only developed better knowledge about the candidates' stances on the EU and policy issues, they have also come to see the differences in these positions more clearly. The claim voiced by Follesdal and Hix (2006) that increased political competition instils cognitive involvement and lead to more informed vote choice is thus borne out. In contrast, the finding that exposure to the debate does not increase support of one's country EU membership runs counter to the expectation that positive coverage of the EU leads to more positive EU attitudes and hence an increase in the EU's perceived legitimacy.

Based on our results, which broadly support the argument about the positive effects of political competition on public support, we suggest that the debate format is an appropriate instrument to foster political debate, citizen involvement and support in the EU. As the recognition of the top candidates running for Commission President increases the likelihood to participate in the 2014 EP elections (Schmitt et al. 2015), exposure to the debate can also have highly desirable behavioural consequences. From this perspective, EU pundits should press for a wide and prominent coverage of TV debates among 'lead candidates' in future EP elections. The 2014 debate can thus serve as a starting point for developing a tradition of televised debates, which already exist in many democracies. This format is particularly important for EP elections, because debates among political leaders competing for political office can serve as a common point of reference (see also Benoit 2014: 4) 
for all European citizens, when otherwise the number of EP election campaigns matches the number of member states. Hence, such a debate can foster an EU-wide campaign format by providing a common frame for national campaigns. In addition, future televised debates will offer exciting opportunities for political communication research on EP election campaigns. Unlike previous effect-analyses focusing on, e.g., the impact of (national) EP campaign spots, (national) EP campaign posters, or (national) media coverage of the EP campaign, a debate among leaders running for Commission President provides the opportunity to compare the impact of an uniform campaign stimulus across different EU member states. Moreover, we have shown that bringing together research on political campaigns in general and TV debates in particular with research on the EU's democratic credentials offers ample opportunities to scrutinize claims that have hitherto not been subject to systematic empirical exploration. We are thus positive that research on the effects of campaign information, such as TV debates, not only improves our understanding about the mechanisms underlying EP campaign effects, but also about their implications for the legitimacy of the EU's political system.

Of course, our data and research design have some limitations. Although our experimental design leaves little room for speculations about how young and well-educated votes react to a debate among political leaders in the EU, we have no empirical evidence about how other groups of voters were influenced by exposure to the debate format. Based on results from debate research, we assume that we rather underestimated the potential impact of the debate. Existing research indicates that debate effects are stronger for voters with lower levels of education (see, e.g., Maier and Faas 2011). One crucial step to remedy this shortcoming is to use the format of representative survey, including an item about whether or not a respondent was watching the debate. This would enable us to find out about the impact of the debate on other groups of voters. In addition, survey data could provide us with insights about who actually watched the debate. Second, the effects we found cannot be generalized to the public-at-large. The media neither provided an appropriate stage for the debate, nor did media broadcasters put a lot of effort into covering this event. ${ }^{14}$ As impressive as it may sound that the Eurovision debate was broadcasted by $55 \mathrm{TV}$ and nine radio channels as well as streamed on 88 websites across the EU and beyond (European Broadcasting Union 2014a, 2014c), most of the media channels airing the debate were, at best, small, second-rate or highly specialized news-channels, which tend to attract only a limited viewership. Moreover, in some member states the debate was accessible only via internet-live-stream or broadcasted the next day (see online appendix 2). Although the moderator of the debate, Monica Maggioni, was keen to stress that the debate would be highly attractive to voters - she argued that the candidates would have the 'chance to tell 400 million voters why they should get Europe's biggest job' (see Maier and Faas 2014: 4) - the available audience ratings were rather 
poor in most countries (see online appendix 2). ${ }^{15}$ Compared with the viewership of TV debates preceding national elections, the Eurovision debate fared poorly. For example, the TV debate in the run-up of the 2013 German national election attracted 17.7 million viewers (Gscheidle and Gerhard 2013: 565). In contrast, the Eurovision debate was watched by 160,000 viewers, less than one per cent of the national debate audience in Germany. Despite some selective audience rating-successes in individual countries, such as Cyprus, the media missed an opportunity to put the European elections in the limelight. In the event that debates between the top candidates running for Commission President will become a feature of future EP election campaigns, the media should definitely increase their coverage of the event and provide airtime in more established programmes to increase the audience ratings. Of course, this criticism also applies to national political parties, which are the main actors in the campaign and, until now, have displayed little enthusiasm to highlight the importance of the debates (see Franklin 2014). Third, not all EU member states are included in our study and some of the sample sizes are small. To obtain a more complete picture for the EU subsequent studies should include all member states with a sufficient number of cases. Increasing the number of observations would also offer the opportunity to run more sophisticated data analyses (e.g., multi-level analyses) and to uncover countryspecific response patterns. Since our results suggest that there are cross-cultural differences, this could be a very promising path for even more rigid testing in the future and for establishing cross-cultural experimental work as a line of research. Finally, from the purview of democratic accountability, it is important for voters to know where political decisions originate in order to be able to assign responsibility. It has been demonstrated in the literature that access to more EU-related information increases the accuracy of citizens' responsibility attributions (Hobolt and Tilley 2014: 148), thus fostering democratic accountability. Our findings suggest that the debate has made our respondents more informed about the EU and led to increased awareness of its relevance for problem-solving. This should, as a result, enable them to 'better ... navigate the complex institutional landscape of the EU' (Hobolt and Tilley 2014: 149). While this is potentially good news from a democratic accountability perspective, our study does not lend itself to sweeping generalizations. Whether or not the Eurovision Debate can be seen as a modest step towards reducing the democratic accountability deficit necessitates further experimental or survey-based research.

\section{Notes}

1. See Franklin (2014: 9-10) for a critical assessment of the institutional change adopted in the Lisbon Treaty. He expects that it is rather unlikely that national 
parties will design their campaigns around the issues highlighted by the different candidates running for Commission President.

2. See, e.g., http://www.spiegel.de/international/europe/editorial-on-the-importan ce-of-the-eu-election-for-european-democracy-a-971766.html; accessed 21 February 2016; http://www.independent.co.uk/news/world/europe/eu-elections-2014-a-v ote-for-europe--or-simply-a-chance-to-put-the-boot-in-9406013.html; http:// www.bbc.com/news/uk-politics-22904941; accessed 29 May 2015.

3. At the same time, increasing competition could also carry negative consequences for the EU's democratic legitimacy. In particular, since political competition creates winners and losers, losers might not 'accept the winning coalition as legitimate' (Hix 2008: 188). Moreover, others argue that enhanced political competition unleashes a 'sleeping giant' (van der Eijk and Franklin 2004: 32), by activating pro or anti EU-orientations, especially when debates revolve around constitutive issues, which relate to the EU's institutional trajectory or its membership base (see Bartolini 2005).

4. For a transcript of the debate see Maier and Faas (2014).

5. In most instances, the debate was watched on TV on 15 May 2014. In some countries, the debate was broadcasted via an Internet live-stream, but not on TV. In addition, in some states the debate was videotaped and broadcasted the next day (see online appendix 2). Due to technical reasons (e.g., because the university was closed when the debate was aired live on TV) recipients in the Czech Republic, France, Romania (Cluj), and Sweden watched the videotaped debate.

6. The remaining 8.2 per cent of the sample started with the simultaneous translation but had to switch to the EBU version due to either bad translation or technical problems.

7. In general, the questionnaires were in English. In some countries, the questionnaires were translated in the native language.

8. Overall, these respondents did understand the debate very well, as their answers show. Only four of these respondents indicated that they understood only about half of the debate. The exclusion of these respondents from data analysis does not affect our results.

9. In seven countries, recipients additionally had the opportunity to spontaneously evaluate the candidates during the debate. To do so, they used a web-based RTR push button system (for a description of the system see Maier et al. 2016). Using this system, individual positive and negative reactions to candidate messages were recorded on a second-by-second basis. Real-time response measurement of candidate messages was successfully implemented in Germany, Poland, Slovenia, and United Kingdom including 210 participants. As it has been demonstrated that using RTR technique in general neither distracts people from following the debate nor increases attention to the debate (Maier 2012), it seems unlikely that this treatment will affect the variables in focus of this paper.

10. It has been shown that in experimental studies with self-recruited participants having a very high level of general interest in politics questionnaire-induced pretest-posttest differences are very rare (see, e.g., Lupfer and Wald 1979). In addition, our pretest-questionnaires show for specific debate-related questions that the specific knowledge is rather low to non-existent. Against this backdrop, the pretest-questionnaire is unlikely to activate pre-existing knowledge.

11. We have tested the existence of pretest-posttest differences for a control group for the design that has been applied to the European debate in the context of 
the 2013 German Federal Election (the data can be downloaded via www.gesis. org/wahlen/gles/daten/; study number ZA5711) and did not find any significant changes for campaign interest, political efficacy, and for different measures of EU-related attitudes for the control group.

12. An analysis of the unweighted or differently weighted data indicates that our weighting procedure does not cause an exaggeration of debate effects: About half of the observed influences are slightly stronger if we do not weight the data or if weight all countries equally whereas the other half is slightly weaker. Furthermore, applying other weighting strategies does not change the reported results substantially. The only exception is that Tsipras is perceived as significantly more in favour of EU integration after the debate than before if these data are not weighted or if we weight all countries equally $(p<.05)$. In the data presented in Table 2 this effect is insignificant. In addition, country differences tend to be more often statistically significant if no or an alternative weighting procedure is used. The results for these alternative weighting procedures are provided in online appendix 3.

13. Our data analyses also show that the reactions to the debate were far from homogenous across the different EU member states: The between-country differences of the measured debate effects display statistical significance for all variables included in our study. Since the goal of this contribution was to look at the aggregate picture, we can neither report nor discuss and explain the potential causes of the observed cross-country differences here, but these findings will need further exploration. In addition, our findings suggest that lessons about the impact of the debate cannot simply be transferred from one country to another. Obviously, the domestic context matters for the effect of campaign messages (see, e.g., Hobolt 2014).

14. For the debate media sweep surrounding the debate, see European Broadcasting Union (2014b).

15. To our knowledge there is no information about the total reach of the debate.

\section{Disclosure statement}

No potential conflict of interest was reported by the authors.

\section{Notes on contributors}

Jürgen Maier is Professor of Political Communication at the University of KoblenzLandau, Germany.

Thorsten Faas is Professor of Political Science at the University of Mainz, Germany

Berthold Rittberger is Professor of Political Science and International Relations at the University of Munich, Germany

Jessica Fortin-Rittberger is Professor of Comparative Politics at the University of Salzburg, Austria

Kalliope Agapiou Josephides, PhD Paris I Panthéon Sorbonne, is Assistant Professor and Jean Monnet Chair in European Political Integration (2001) at the University of Cyprus, Cyprus 
Susan Banducci is professor in Politics and director of the Exeter Q-Step Centre at the University of Exeter, UK

Paolo Bellucci is Professor of Political Science at the University of Siena, Italy

Magnus Blomgren is Associated Professor in Political Science at Umeå University, Sweden

Inta Brikse was Professor of Communication, University of Latvia, Riga, Latvia

Karol Chwedczuk-Szulc is Associate Professor in Political Science at the University of Wrocław, Poland

Marina Costa Lobo is Principal Researcher at the Institute of Social Sciences of the University of Lisbon, Portugal

Mikolaj Cześnik is Professor of Political Science at the University of Social Sciences and Humanities, Warsaw, Poland, and a member of the Polish National Election Study team Anastasia Deligiaouri is Adjunct Assistant Professor in Political Communication at the Western Macedonia University of Applied Sciences (TEI), Kastoria, Greece

Tomaž Deželan is Associate Professor of political science and Jean Monnet Chair for citizenship education at the Faculty of Social Sciences, University of Ljubljana, Slovenia Wouter de Nooy is a member of ASCoR Amsterdam School of Communication, Amsterdam, Netherlands

Aldo Di Virgilio was Professor of Political Science at the University of Bologna, Italy

Florin Fesnic is a researcher at the University of Cluj, Cluj, Romania

Danica Fink-Hafner is Professor of Political parties, interest groups and policy analysis, University of Ljubljana, Slovenia

Marijana Grbeša is Assistant Professor at the Faculty of Political Science, University of Zagreb, Croatia

Carmen Gabriela Greab is Researcher at Babes-Bolyai University, Faculty of Political Science, Cluj-Napoca, Romania

Andrija Henjak is a researcher at the University of Zagreb, Croatia

David Nicolas Hopmann is professor with special responsibilities (mso) at the Centre for Journalism, Department of Political Science, University of Southern Denmark, Odense, Denmark

David Johann is Post-Doctoral Research Associate at the German Centre for Higher Education Research and Science Studies (DZHW) and Senior Research Fellow at the University of Vienna, Austria

Gábor Jelenfi is researcher at the MTA-ELTE Peripato Research Group, Faculty of Social Science, Eötvös Lóránd University, Budapest, Hungary

Jurate Kavaliauskaite is a researcher at Vilnius University, Lithuania, and a member of the Lithuanian National Election Study team

Zoltán Kmetty is a Research Fellow at MTA-ELTE Peripato reserach group, and Senior Lecturer at the Eötvös Loránd University Faculty of Social Science, Hungary

Sylvia Kritzinger is Professor for Methods in the Social Sciences at the Department of Government, University of Vienna, Austria

Pedro C. Magalhães is research fellow at the Institute of Social Sciences of the University of Lisbon, Portugal 
Vincent Meyer is a sociologist, Professor of information and communication sciences, at the University Nice Sophia Antipolis, France

Katia Mihailova is Assistant Professor of Sociology of Media and Communications at the Department of Economic Sociology, UNWE, Sofia, Bulgaria

Mihail Mirchev is Professor of Sociology at the Department of Political Studies, UNWE, Sofia, Bulgaria

Ville Pitkänen is senior researcher at the Centre for Parliamentary Studies, University of Turku, Finland

Aine Ramonaite is Professor of Political Science at Vilnius University, Lithuania

Theresa Reidy is a lecturer in the Department of Government at University College Cork, Ireland

Marek Rybar is Associate Professor of Political Science at the Masaryk University Brno, Czech Republic

Carmen Sammut is a researcher at the University of Malta, Msida, Malta

José Santana-Pereira is a Postdoctoral Researcher at the Institute of Social Sciences, University of Lisbon, Portugal, and a Guest Assistant Professor at ISCTE-IUL, Portugal

Guna Spurava is a researcher at the University of Latvia, Riga, Latvia

Lia-Paschalia Spyridou is Lecturer in Journalism and Media at the Department of Social and Political Sciences at the University of Cyprus, Cyprus.

Adriana Stefanel, doctor in Sociology, Assistant Profesor at the University of Bucharest, Romania

Václav Štětka is Lecturer in Communication and Media Studies, Loughborough University, UK, and Senior Researcher at Charles University in Prague, Czech Republic

Aleksander Surdej is Professor of International Political Economy at the Cracow University of Economics and the head of the Department of European Studies

Róbert Tardos, Senior Research Fellow, Peripato Research Group of Comparative Social Dynamics of the Hungarian Academy of Sciences at ELTE University, Budapest, Hungary

Dimitris Trimithiotis is Adjunct Lecturer of Media at the University of Cyprus, Cyprus Crisiano Vezzoni is researcher at the University of Trento, Italy

Aneta Világi is Assistant Professor of Political Science at the Comenius University in Bratislava, Slovakia

Gergo Zavecz is a researcher at the Central European University, Budapest, Hungary

\section{ORCID}

Sylvia Kritzinger (D) http://orcid.org/0000-0003-2765-8200

\section{References}

Abramowitz, A. (1978) 'The impact of a presidential debate on voter rationality', American Journal of Political Science 22: 680-90. 
Bartolini, S. (2005) Restructuring Europe: Centre Formation, State Building and Political Structuring between the Nation State and the European Union, Oxford: Oxford University Press.

Benoit, W.L. (2014) Political Election Debates. Informing Voters About Policy and Character, Lanham: Lexington Books.

Benoit, W.L., Hansen, G.J. and Verser, R.M. (2003) 'A meta-analysis of the effects of viewing U.S. presidential debates', Communication Monographs 70: 335-50.

Best, S.J. and Hubbard, C. (1999) 'Maximizing "minimal effects": The impact of early primary season debates on voter preferences', American Politics Quarterly 27: 450-67.

Dahl, R. (1971) Polyarchy: Participation and Opposition, New Haven: Yale University Press. van der Eijk, C. and Franklin, M. (2004) 'Potential for contestation on European matters at national elections in Europe' in G. Marks and M.R. Steenberger (eds.), European Integration and Political Conflict, Cambridge: Cambridge University Press, pp. 32-50.

Dinter, J. and Weissenbach, K. (2015) 'Alles neu! das experiment TV-Debatte im Europawahlkampf 2014', in M. Kaeding and N. Switek (eds.), Die Europawahl 2014. Spitzenkandidaten, Protestparteien und Nichtwähler, Wiesbaden: Springer, pp. 233-45.

Druckman, J.N. and Kam, C.D. (2011). 'Students as experimental participants: in defense of a 'narrow data base", in J.N. Druckman, D.P. Green, J.H. Kuklinski and A. Lupia (Eds.), Cambridge Handbook of Experimental Political Science, Cambridge: Cambridge University Press, pp. 41-57.

European Broadcasting Union (2014a) Eurovision debate, available at http://www3. ebu.ch/content/online (accessed 22 October 2014).

European Broadcasting Union (2014b) Debate media sweep. 15-16 May 2014, available at http://www3.ebu.ch/files/live/sites/ebu/files/News/2014/05/Debate\%20media\% 20coverage\%2015-16May.pdf (accessed 19 June 2015).

European Broadcasting Union (2014c) Broadcasters Eurovision presidential debate, available at http://www.europarl.europa.eu/pdf/divers/broadcasters.pdf (access 6 October 2016).

Exadaktylos, F., Espín, A.M. and Brañas-Garza, P. (2013) 'Experimental subjects are not different', Scientific Reports 3(1213): 1-6.

Follesdal, A. and Hix, S. (2006) 'Why there is a democratic deficit in the EU: A response to Majone and Moravcsik', JCMS: Journal of Common Market Studies 44: 533-62.

Franklin, M. (2014) 'Why vote at an election with no apparent purpose? Voter turnout at elections to the European Parliament', European Policy Analysis 4: 1-11.

German Longitudinal Election Study (2014) TV debate analysis, available at http://gles. eu/wordpress/english/design/tv-duell/ (accessed 26 October 2014).

Gscheidle, C. and Gerhard, H. (2013) 'Berichterstattung zur Bundestagswahl 2013 aus Sicht der Zuschauer', Media Perspektiven 12, 558-73.

Hix, S. (2008) What's Wrong with the European Union and How to Fix It, Cambridge: Polity Press.

Hix, S. (2013) 'Why the 2014 European elections matter: ten key votes in the 2009-2013 European parliament', European Policy Analysis 15: 1-16.

Hix, S. and Hoyland, B. (2013) 'Empowerment of the European parliament', Annual Review of Political Science 16: 171-89.

Hobolt, S. (2014) 'A vote for the president? The role of Spitzenkandidaten in the 2014 European parliament elections', Journal of European Public Policy 21: 1528-40.

Hobolt, S.B. and Tilley, J. (2014) Blaming Europe? Responsibility without Accountability in the European Union, Oxford: Oxford University Press.

Holbrook, T.M. (1999) 'Political learning from presidential debates', Political Behavior 21: 67-89. 
Jacoby, J., Troutman, T.R. and Whittler, T.E. (1986) 'Viewer miscomprehension of the 1980 presidential debate: A research note', Political Psychology 7: 297-308.

Kaid, L.L., McKinney, M.S. and Tedesco, J.C. (2000) Civic Dialogue in the 1996 Presidential Campaign. Candidates, Media, and Public Voices, Creskill: Hampton Press.

Lazarsfeld, P.F., Berelson, B. and Gaudet, H. (1944) The People's Choice. How the Voter Make Up His Mind in a Presidential Campaign, New York: Columbia University Press.

Lupfer, M. and Wald, K. (1979) 'An experimental study of the first Carter-Ford debate', Experimental Study of Politics 7(1): 20-40.

Maier, J. (2012) 'Führt der Einsatz von Real-Time-Response-Technik zu einer anderen Wahrnehmung von Fernsehdebatten? Ergebnisse zweier Experimente zur externen Validität von Echtzeitmessungen', Politische Psychologie 2: 7-21.

Maier, J. (2015) 'Neue Wahlkampfinstrumente als Mittelgegen die Vertrauenskrise der EU? Die Wirkung der 'Eurovision Debate' im Europawahlkampf 2014 und die Rolle der sozialen Medien', Datenschutz und Datensicherheit - DuD 39: 308-11.

Maier, J. and Faas, T. (2003) 'The affected German voter: televised debates, follow-up communication and candidate evaluations', Communications 28: 383-404.

Maier, J. and Faas, T. (2011) "Miniature campaigns' in comparison: The German televised debates, 2002-09', German Politics 20: 75-91.

Maier, J. and Faas, T. (2014).Transcription of the 'Eurovision debate' in the run-up to the European parliamentary election 2014, available at http://www.uni-koblenz-landau. de/de/komepol/papers/working-paper-nr-2-2014 (accessed 29 May 2015).

Maier, J., Rittberger, B. and Faas, T. (2016) 'Debating Europe: effects of the "Eurovision debate" on EU attitudes of young German voters and the moderating role played by political involvement', Politics and Governance 4(1): 55-68.

Maricchiolo, F., Gnisci, A. and Bonaiuto, M. (2010) 'Political leaders' communicative style and audience evaluation in an Italian general election debate', in I. Poggi, F. D'Errico, L. Vincze and A. Viciarelli (eds.), Multimodal Communication in Political Speech: Shaping Minds and Social Action, Berlin: Springer, pp. 114-32.

Maurer, M., Reinemann, C., Maier, J. and Maier, M. (2007) Schrödergegen Merkel. Wahrnehmung und Wirkung des TV-Duells 2005 im Ost-West-Vergleich, Wiesbaden: Verlag für Sozialwissenschaften.

McKinney, M.S. and Carlin, D.B. (2004) 'Political campaign debates', in L.L. Kaid (ed.), Handbook of Political Communication Research, Mahwah: Erlbaum, pp. 203-34.

McKinney, M.S. and Warner, B.R. (2013) 'Do presidential debates matter? Examining a decade of campaign debate effects', Argumentation and Advocacy 49: 238-58.

Pfau, M. (1987) 'The influence of intraparty debates on candidate preference', Communication Research 14: 687-97.

Publications Office of the European Union (2010) Official Journal of the European Union. Volume 53, 30 March 2010, available at http://eur-lex.europa.eu/ legal-content/EN/TXT/PDF/?uri=OJ:C:2010:083:FULL\&from=DE (accessed 29 May 2015).

Reif, K. and Schmitt, H. (1980) 'Nine second-order national elections -A conceptual framework for the analysis of election result', European Journal of Political Research 8: 3-44.

Rittberger, B. (2012) 'Institutionalizing representative democracy in the European Union: the case of the European parliament', JCMS: Journal of Common Market Studies 50(s1): 18-37.

Schmitt, M., Hobolt, S. and Popa, S.A. (2015) 'Does personalization increase turnout? Spitzenkandidaten in the 2014 European parliament elections', European Union Politics 16: 347-68. 
Skoko, B. (2005) 'Role of TV debates in presidential campaigns. Croatia's case of 2005', Politička Misao 5: 97-117.

Tulli, U. (2016) 'Electing the European parliament: some historiographical notes', The International History Review 38: 214-28.

de Vreese, C.H. and van der Brug, W. (2016) 'Conclusion', in W. van der Brug and C.H. de Vreese (eds.), (Un)Intended Consequences of European Parliamentary Elections, Oxford: Oxford University Press, pp. 277-87.

Wald, K.D. and Lupfer, M.B. (1978) 'The presidential debate as a civics lesson', Public Opinion Quarterly 42: 342-53.

Weaver, D. and Drew, D. (2001) 'Voter learning and interest in the 2000 presidential election: did the media matter?', Journalism \& Mass Communication Quarterly 78: 787-98.

Zhu, J.-H., Milavsky, R.J. and Biswas, R. (1994) 'Do televised debates affect image perception more than issue knowledge? A study of the first 1992 presidential debate', Human Communication Research 20: 302-33. 